\title{
Design and Fabrication of Densified Biomass Briquette Maker Machine
}

\author{
Omkar P. Bhatkar ${ }^{1}$, Shripad S. Patil ${ }^{2}$, Sourabh P.Tambe ${ }^{3}$, Nihar N. Wafelkar ${ }^{4}$, Prasad P. \\ Manjarekar ${ }^{5}$
}

\author{
${ }^{1}$ Assistant Professor, Department of Mechanical Engineering, Rajendra Mane College of Engineering \& Technology, Ambav \\ Affiliation Name: University of Mumbai, India \\ 2,3,4,5 Students, Department of Mechanical Engineering, Rajendra Mane College of Engineering \& Technology, Ambav \\ Affiliation Name: University of Mumbai, India
}

\begin{abstract}
The project we designing \& fabricating is to reduce the problems of Cutting Trees for fire logs. "Leaf Log Maker Machine" is designed to make dry leaves get compressed and made to logs as a fuel. Typically, dead leaves are dumped a lot in landfills and one of the problems with leaving wet leaves to decompose like this is that they give off methane 20 times more poisonous gas than carbon dioxide. In contrast, when leaves are burnt, they only give off the carbon they absorb while on the tree they add nothing extra to the environment. This machine is compact, easily accessible \& eco-friendly. It can also able to compress wood wastes, papers \& tin cans. This machine is to make fuels from the natural resources like dry leaves, instead of cutting them. This machine is easy to understand the operation to user. It had come over many changes and modifications within it.
\end{abstract}

Keywords- Briquetting, Biomass, Deforestation, Densification, Environmental friendly briquettes, Paper pulp.

\section{INTRODUCTION}

Leaf Log Maker Machine is a concept to make the dry leaves to be compressed for useful fire logs. Actually, the leaves which are left in landfills get decomposed and produce the methane gas (toxic level is 20 times more than carbon-di-oxide) harmful to human nature [1]. In contrast, when leaves are burnt, they only give off the carbon they absorb while on the tree they add nothing extra to the environment. So, we planned to make those leaves as fire logs instead of leaving in landfills, for the purpose of reducing the tree cutting for the fire logs which leads to one of the way of the Deforestation [1].

Biomass briquetting is the densification of loose biomass material to produce compact solid composites of different sizes with the application of pressure. Briquetting of residues takes place with the application of pressure, heat and binding agent on the loose materials to produce the briquettes. Two different types of densification technologies are currently in use. The first, called pyrolizing technology relies on partial pyrolysis of biomass, which is mixed with binder and then made into briquettes by casting and pressing. The second technology is direct extrusion type, where the biomass is dried and directly compacted with high heat and pressure [2].

Due to the present world's energy crisis and its related environmental issues as well as increasing trend of fossil fuel prices, renewable energy source is an essential matter. Biomass briquettes are a renewable source of energy and they avoid adding fossil carbon to the atmosphere. They are made from biomass and are a replacement for fossil fuels, and can be used to heat boilers in manufacturing plants, and also have applications in developing countries.

Biomass Briquetting Technology

Biomass densification represents a set of technology for the conversion of biomass residues into a convenient fuel. Depending on types of equipment used it could be categorised into five main types [3]:

1. Piston press densification

2. Screw press densification

3. Roller press densification

4. Pelletizing

5. Low pressure manual presses briquetting.

We use piston press densification technology to make log with the help of paper pulp as a binder.

\section{MATERIAL AND METHODOLOGY}

For the purpose of study, dry leaves was used for performance evaluation of machine. And also paper pulp was used as binding agent mainly to overcome the major problem of material compaction [4].

\section{A. Design and construction}

A biomass briquetting machine was designed and constructed (Fig.1). The briquetting machine was equipped with 20 tone hydraulic bottle jack with spring return mechanism. Hydraulic bottle jack applies pressure with the help of piston on biomass inside cylindrical 
mould measuring $105 \mathrm{~mm}$ internal diameter and $150 \mathrm{~mm}$ length.

The mould was splitted in two section for removing the briquette easily. The hydraulic bottle jack used applies pressure about 3000 psi on biomass. The machine was fabricated using EN8 carbon steel because of its properties like good tensile Strength and it often used for making shaft, gear, stressed, pins, studs etc.

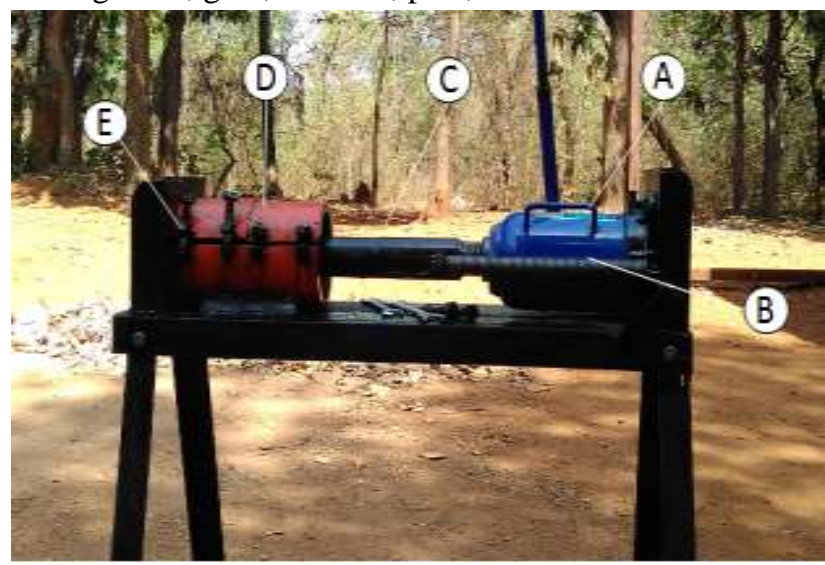

Fig. 1 : The Leaf Log Maker Machine

A-Hydraulic Jack, B-Springs, C-Piston,

D-Cylinder, E-Nut \& Bolt

\section{B. Preparation of briquette}

The briquette was prepared at Rajendra Mane College of Engineering and Technology (Devrukh), University of Mumbai, India using manual hydraulic briquette machine with single cylindrical mould. The binders made with the help of waste paper which were manually torn to small pieces and sucked in water to form gelatinised paste. 3-5 days of socking in water was required to get a sticky solution.

Binder was added after each stroke of ram to get proper uniformity of $\log$. The pressure was maintained at 3000psi [5] for $5 \mathrm{~min}$ for making each briquette. The choice of quantity of binder was used based on the optimum amount for production of briquettes best density high stability and calorific value.

\section{Biomass binder mixture}

Dry leaves was mixed with an already prepared paper pulp for carrying out various tests. First test were carried out without using binder. Second test were carried out with the help of addition of small amount of binder in between each stroke and in third test paper pulp is mixed with dry leaves in proportion of 100:30 and used for making briquette [4]. The biomass-binder mixture was hand fed into mould and compacted to form the briquettes.

\section{PERFORMANCE EVALUATION}

For the performance evaluation, three briquette samples were made from the dry leaves for evaluation. During the process of densification, the following statistic: time for loading biomass into moulds, $\mathrm{t} 1$, sec, time for compressing the biomass, $\mathrm{t} 2$, sec, and time for ejecting the biomass briquettes, $\mathrm{t} 3$, sec, were observed and recorded following after [5][6]. The production capacity of the machine in $\mathrm{kg} / \mathrm{hr}$ was also recorded. On ejection of the briquettes from the moulds, the mass and the dimensions of the briquettes were taken to determine the density in $\mathrm{g} / \mathrm{cm} 3$. The compressed density (density immediately after compression) of the briquette was determined immediately after ejection from the moulds as the ratio of measured weight to the calculated volume [5].

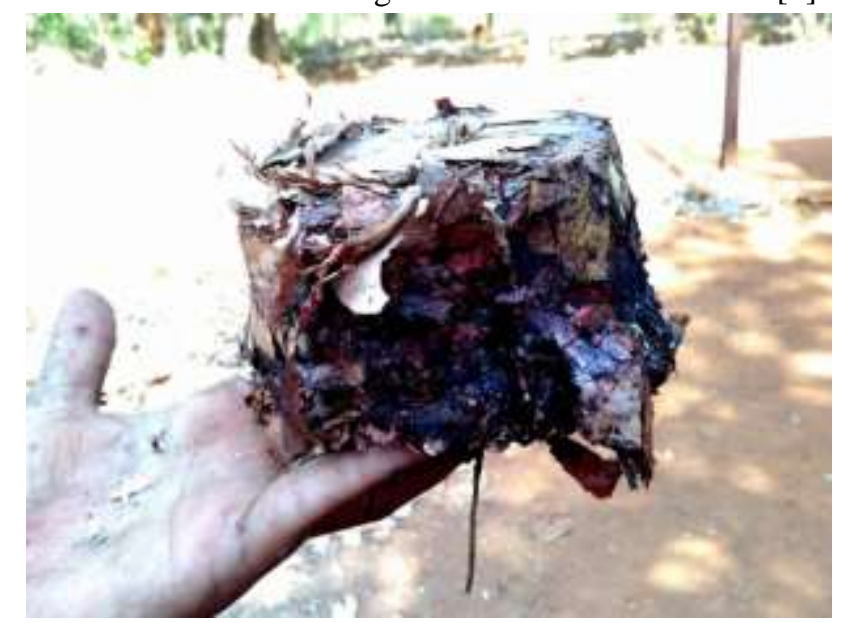

Fig. 2: Leaf Logs

\section{RESULTS}

The mean biomass loading time, $\mathrm{t} 1$, mean biomass compaction time, $\mathrm{t} 2$, and the mean briquette ejection time, t3 as well as their percentages of the total production time were recorded as shown in Table 1.

Table.1: Production time

\begin{tabular}{|l|l|l|l|}
\hline $\begin{array}{l}\text { Mean production } \\
\text { time }\end{array}$ & & $\begin{array}{l}\text { Time } \\
(\mathbf{S e c})\end{array}$ & $\begin{array}{l}\text { production time } \\
\text { in percentage }\end{array}$ \\
\hline $\begin{array}{l}\text { Biomass loading } \\
\text { time }\end{array}$ & $\boldsymbol{t}_{\mathbf{1}}$ & 60 & 11.5384 \\
\hline $\begin{array}{l}\text { Biomass } \\
\text { compaction time }\end{array}$ & $\boldsymbol{t}_{\mathbf{2}}$ & 270 & 51.9231 \\
\hline $\begin{array}{l}\text { Briquette ejection } \\
\text { time }\end{array}$ & $\boldsymbol{t}_{\mathbf{3}}$ & 190 & 36.5385 \\
\hline Total & & 520 & 100 \\
\hline
\end{tabular}

The mean production time for making one biomass briquette is 520 seconds $(8.6667$ minutes $)$. The production capacity of machine is about $2.5 \mathrm{~kg} / \mathrm{hr}$.

\section{Density of biomass Briquette}

The density of briquettes are shown in Table 2. The influence of binder level was significant on density of 
briquette. The compressed density ranged from 0.3926 to $0.7699 \mathrm{gm} / \mathrm{cm}^{3}$ on different addition of paper pulp (binder). The maximum compressed density of 0.7699 $\mathrm{gm} / \mathrm{cm} 3$ was reached by adding binder in between each stroke of piston for uniformity. Without addition of binder density of $0.3926 \mathrm{gm} / \mathrm{cm}^{3}$ was reached and mixing the binder $30 \%$ in dry leaves density found 0.5389 $\mathrm{gm} / \mathrm{cm}^{3}$.

Table.2: Physical properties of briquette

\begin{tabular}{|l|c|}
\hline Biomass-binder mixture & $\begin{array}{c}\text { Compressed } \\
\text { density }\left(\mathrm{gm} / \mathrm{cm}^{3}\right)\end{array}$ \\
\hline Without binder & 0.3926 \\
\hline $\mathbf{3 0 \%}$ of binder & 0.5389 \\
\hline $\begin{array}{l}\text { Small amount binder mixed in } \\
\text { between each stroke of piston }\end{array}$ & 0.7699 \\
\hline
\end{tabular}

Calorific values of briquettes formed having paper pulp binder was found as $18.14 \mathrm{MJ} / \mathrm{kg}$. The briquettes formed gave energy cost less than 0.16 Rs./MJ [4].

\section{CONCLUSION}

The study on development of leaf log making machine is of great importance to make briquette at lower cost. Agricultural residue and saw dust also provide an enormous untapped fuel resources.

The following conclusions were arrived at from study:

1. Leaf log making machine suitable for the production of dry leaves briquette on a small scale with production capacity $2.5 \mathrm{~kg} / \mathrm{hr}$.

2. The density of dry leaves briquette was found to be significantly affected by the binder level.

3. Briquette with satisfactory quality was produced using Leaf Log Making Machine. However briquette quality was decided with the help of compressed density.

4. Approximate value of energy cost of wood is 0.17 rupees per mega joule and approximate value of energy cost of briquette is less than 0.16 rupees per mega joule.

\section{REFERENCES}

[1] Manoj M, Logeshwaran S, Design and Fabrication of Leaf alof Maker Machine, JIRAS, Volume No.1, Issue No.2. Page No: 50 -56, JUL DEC:2015

[2] Ravina Sanap, Madhuri Nalawade, Jyoti Shende, Pinku Patil. Automatic Screw Press Briquette Making Machine, IJNREME Vol. 3, Issue 1, pp: (19-23), Month: January-April 2016

[3] Maninder, Rupinderjit Singh Kathuria, Sonia Grover. Using Agricultural Residues as a Biomass Briquetting: An Alternative Source of Energy,
IOSRJEEE Volume 1, Issue 5 (July-Aug 2012), PP 11-15.

[4] Daham Shyamalee, A.D.U.S. Amarasinghe, N.S. Senanayaka . Evaluation of different binding materials in forming biomass briquettes with saw dust, IJSRP, Volume 5, Issue 3, March 2015

[5] Obi, O.F., Akubuo,C.O.,Okonkwo,W.I. Development of an Appropriate Briqueting Machine for Use in Rural Communities, IJEAT, Volume 2, Issue 4, April 2013.

[6] Adekoya, L. O. 'Briquetting of Agricultutral Wastes: A Preliminary Study'. Proceedings of the CIGR Inter-sections Symposium.pp 218-225

[7] D.C.Chinyere, S.N.Asoegwu, G.I.Nwandikom "An evaluation of briquettes from saw dust and corn starch binder' IJST, vol.2 Issue 7

[8] Oladeji J.T., Enweremadu C.C 'Effects of some processing parameters on physical and densification characteristics of corncobs briquetees, IJEE, Vol 2, Issue 1 pp 22-27 May2012

[9] Reed T.B., Trefek G, Diaz L. 'Biomass densification energy requirements in thermal conversion solid wastes and biomass' American chemical society, Washington DC, 1980 